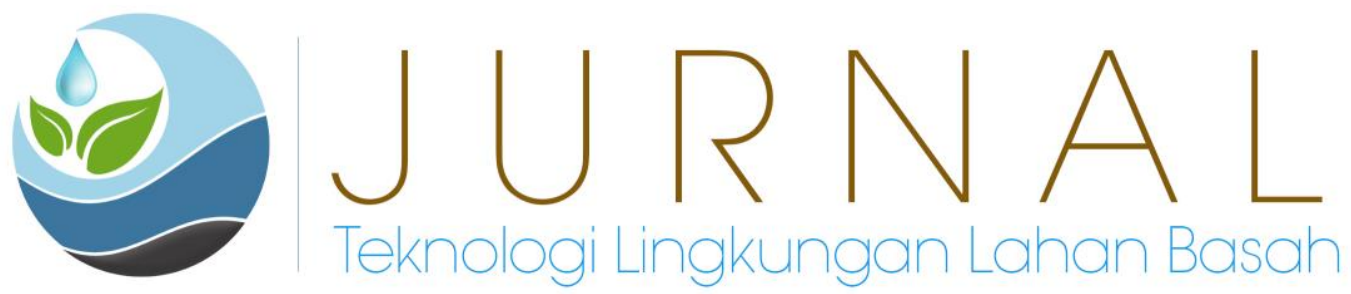

\title{
PERBANDINGAN KUAT TEKAN BATA PLASTIK BERJENIS POLYPROPYLENE (PP), POLYETHYLENE TEREPHTHALATE (PET) DAN HIGH DENSITY POLYETHYLENE (HDPE)
}

\author{
Muhammad Ridho Reksi ${ }^{1}$, Dian Rahayu Jati ${ }^{1}$ dan Yulisa Fitrianingsih ${ }^{1}$ \\ ${ }^{1}$ Jurusan Teknik Lingkungan Universitas Tanjungpura
}

E-mail : rdh.rksi@student.untan.ac.id

\begin{abstract}
Plastic waste needs attention because it can cause serious problems if not managed properly. Of the various types of plastics, the most widely disposed of to the environment are Polypropylene, Polyethylene Terephthalate, and High-Density Polyethylene which are usually in the form of plastic bags and bottles. This research was conducted to make bricks made of plastic as an alternative material for infrastructure that is economical, strong, and durable, which is seen based on the compressive strength value based on its type, namely PP, PET, and HDPE plastic bricks. The compressive strength testing phase is carried out three times in each type. The selling price of plastic bricks is determined by the Markup pricing method. The process of plastic bricks making includes collecting plastic waste, washing, drying, chopping, melting, and printing. Based on the research results, the plastic bricks produced from the types of PET, HDPE, and PP are in the form of blocks with a size of $19 \mathrm{~cm} x 10 \mathrm{~cm} x 6.5 \mathrm{~cm}$, where the PET type brick requires $5.1 \mathrm{~kg}$ of waste, $3.6 \mathrm{~kg}$ of HDPE type, and the type of PP as much as $3 \mathrm{~kg}$. The compressive strength test values for PP, PET, and HDPE plastic bricks have met the compressive strength standards based on SNI 15-2094-2000, with the highest average compressive strength test values found in PP plastic bricks of $246 \mathrm{~kg} / \mathrm{cm}^{2}$, plastic bricks HDPE type $166 \mathrm{~kg} / \mathrm{cm}^{2}$, and plastic brick type PET $98.7 \mathrm{~kg} / \mathrm{cm}^{2}$. The selling price of plastic bricks without including the purchase price of plastic as raw material for making plastic bricks (Scenario I) for PP plastic bricks costs Rp1.907,00/brick, PET types Rp3.024,00/brick, and HDPE types Rp3.464,00/brick. While the selling price of plastic bricks by entering the purchase price of plastic as raw material for making plastic bricks (Scenario II) for PP plastic bricks Rp2.867,00/brick, PET type Rp4.624,00/brick, and HDPE type Rp3.944,00/brick.
\end{abstract}

Keywords: Compressive Strength, Markup Pricing, Plastic Brick.

\begin{abstract}
Abstrak
Sampah plastik perlu mendapatkan perhatian karena menimbulkan masalah yang serius jika tidak dikelola dengan baik. Dari berbagai jenis plastik, yang paling banyak dibuang ke lingkungan adalah jenis Polypropylene, Polyethylene Terephthalate, dan High Density Polyethylene yang biasanya dalam bentuk kantong dan botol plastik. Penelitian ini dilakukan guna membuat bata berbahan plastik sebagai bahan alternatif infrastruktur yang bersifat ekonomis, kuat dan tahan lama yang dilihat berdasarkan nilai kuat tekan berdasarkan jenisnya, yaitu bata plastik jenis PP, PET, dan HDPE. Tahap pengujian kuat tekan dilakukan sebanyak tiga kali pengulangan di setiap jenisnya. Harga jual bata plastik ditentukan dengan metode Markup pricing. Proses pembuatan bata plastik yaitu pengumpulan sampah plastik, pencucian, penjemuran, pencacahan, pelelehan, dan pencetakan. Berdasarkan hasil penelitian, bata plastik yang dihasilkan dari jenis PET, HDPE, dan PP berbentuk balok dengan ukuran $19 \mathrm{~cm} \times 10 \mathrm{~cm} \times 6,5 \mathrm{~cm}$, dimana bata jenis PET memerlukan sampah sebanyak $5,1 \mathrm{~kg}$, jenis HDPE sebanyak 3,6 kg, dan jenis PP sebanyak $3 \mathrm{~kg}$. Nilai uji kuat tekan pada bata plastik jenis PP, PET, dan HDPE telah memenuhi standar kuat tekan berdasarkan SNI 15-2094-2000, dengan nilai uji kuat tekan rata-rata tertinggi terdapat pada bata plastik jenis PP sebesar $246 \mathrm{~kg} / \mathrm{cm}^{2}$, bata plastik jenis HDPE $166 \mathrm{~kg} / \mathrm{cm}^{2}$, dan bata plastik jenis PET 98,7 kg/ $\mathrm{cm}^{2}$. Harga jual bata plastik tanpa memasukkan harga beli plastik sebagai bahan baku pembuatan bata plastik (Skenario I) pada bata plastik jenis PP seharga Rp1.907,00/bata, jenis PET Rp3.024,00/bata, dan jenis HDPE Rp3.464,00/bata. Sedangkan harga jual bata plastik dengan memasukkan harga beli plastik sebagai bahan baku pembuatan bata plastik (Skenario II) pada bata plastik jenis PP Rp2.867,00/bata, jenis PET Rp4.624,00/bata, dan jenis HDPE Rp3.944,00/bata.
\end{abstract}

Kata Kunci: Bata Plastik, Kuat Tekan, Markup Pricing. 


\section{PENDAHULUAN}

Sampah menjadi permasalahan yang sulit ditangani oleh kota-kota yang ada di Indonesia. Jumlah timbulan sampah di Indonesia pada tahun 2019 mencapai 17.206,72 $\mathrm{m}^{3} / \mathrm{hari}$ dengan penduduk 268.100.000 jiwa. Kalimantan Barat merupakan salah satu Provinsi yang mengalami permasalahan sampah, dimana timbulan sampah mencapai $1.834,4$ $\mathrm{m}^{3} /$ hari pada tahun 2019 dengan jumlah penduduk sebesar 5.069.000 jiwa (Statistik Lingkungan Hidup Indonesia, 2020; Badan Pusat Statistik, 2020). Sampah plastik yang susah terurai oleh mikroorganisme jika tidak dikelola dengan baik dapat menimbulkan masalah yang serius. Jenis-jenis plastik yang sering diolah adalah Polypropylene (PP), Polistirena (PS), Polyethylene Terephthalate (PET), Polyvinyl Chloride (PVC), dan High Density Polyethylene (HDPE), dimana plastik yang paling banyak dibuang ke lingkungan adalah jenis Polypropylene (PP), Polyethylene Terephthalate (PET) dan High Density Polyethylene (HDPE) yang biasanya dalam bentuk kantong dan botol plastik (Kamaliah, 2019).

Pada penelitian terdahulu Sari dan Nusa (2019) menyatakan bahwa plastik dapat dimanfaatkan menjadi material konstruksi paving block, bata beton dan jalan seperti aspal dan beton. Sampah plastik mudah meleleh namun apabila sudah berada pada suhu normal dapat menjadi sangat keras dan cocok digunakan sebagai bahan campuran pembuatan bata beton dan paving block. Penelitian ini dilakukan guna membuat batu bata berbahan plastik dari sampah plastik jenis PP, PET, dan HDPE sebagai bahan alternatif infrastruktur yang bersifat ekonomis, kuat dan tahan lama. Jenis bata plastik dengan uji kuat tekan tertinggi akan menjadi bata plastik paling baik, dimana setiap jenis bata plastik akan dibandingkan dengan nilai uji kuat tekan pada bata merah sebagai kontrol yang memenuhi SNI 15-2094-2000 tentang Bata Merah Pejal untuk Pasangan Dinding. Oleh karena itu penelitian ini bertujuan untuk menganalisis proses pembuatan bata plastik, menganalisis uji kuat tekan bata plastik berdasarkan jenisnya, dan menganalisis harga jual bata plastik jenis Polypropylene (PP), Polyethylene Terephthalate (PET), dan High Density Polyethylene (HDPE).

\section{METODE PENELITIAN}

\section{A. Lokasi dan Waktu Penelitian}

Penelitian dilakukan pada Januari 2021. Pembuatan bata plastik dilaksanakan di Laboratorium Kualitas Air Fakultas Teknik. Pengujian kuat tekan bata plastik dilakukan di Laboratorium Bahan dan Konstruksi Fakultas Teknik. Sampah plastik diperoleh dari TPS sekitar Kecamatan Sungai Raya. Sampel bata merah dibeli pada Toko Bangunan Mitra Jaya, Pontianak.

\section{B. Alat dan Bahan Penelitian}

Alat yang digunakan pada penelitian ini yaitu kotak wadah sampah, timbangan, APD, stik kayu, gunting, wadah aluminium ukuran $21 \mathrm{~cm} x$ tinggi $15 \mathrm{~cm}$, oven BINDER RS422, cetakan persegi panjang 10 x 4,5 x $19 \mathrm{~cm}$, Compression Machine $1500 \mathrm{kN}$ dan kamera. Bahan yang digunakan pada penelitian ini yaitu cat minyak dan sampah plastik jenis Polypropylene, Polyethylene Terephthalate, dan High Density Polyethylen.

\section{Pengumpulan Sampah Plastik}

Pengambilan sampah plastik dilakukan secara langsung dari TPS. Sampah plastik diambil sebanyak $3 \mathrm{~kg}$ sampah plastik jenis Polypropylene (PP), $5 \mathrm{~kg}$ jenis Polyethylene Terephthalate (PET), dan $4 \mathrm{~kg}$ jenis High Density Polyethylen (HDPE). 


\section{Langkah Kerja Pembuatan Bata Plastik}

1. Persiapan Alat dan Bahan

Alat yang disiapkan berupa APD, stik kayu, gunting, timbangan, baskom, wadah tempat pembakar dan oven untuk proses pelelehan, cetakan bata plastik kemudian bahan yang digunakan yaitu tiga jenis plastik yaitu Polypropylene (PP), Polyethylene Terephthalate (PET) dan High Density Polyethylen (HDPE).

2. Proses Pencucian Sampah Plastik

Proses pencucian sampah plastik yaitu sampah plastik dicuci dengan air dengan tiga kali pengulangan. Tujuan pencucian sampah plastik yaitu untuk menghilangkan kotoran yang menempel pada permukaan plastik yang berasal dari TPS. Sehingga bata plastik yang dihasilkan dengan kondisi bersih dan terbebas dari material lain.

3. Proses Penjemuran Sampah Plastik

Sampah plastik dijemur langsung di bawah sinar matahari hingga keadaan benar-benar kering selama \pm 3 jam penjemuran. Proses penjemuran berfungsi sebagai pengurangan kadar air pada sampah plastik guna mempermudah pada proses pelelehan.

4. Proses Pencacahan Sampah Plastik

Sampah plastik dicacah dengan menggunakan gunting, dengan ukuran plastik $5 \mathrm{~cm}$. Proses pencacahan berfungsi untuk memperbesar luas permukaan sampah plastik, sehingga pada proses pemanasan sampah plastik dapat dengan mudah meleleh.

5. Proses Pelelehan Plastik

Proses pelelehan sampah plastik yaitu, sampah plastik dilelehkan menggunakan oven dan wadah (aluminium) bervolume $5.734 \mathrm{~cm}^{3}$.

6. Pencetakan Bata Plastik

Proses pencetakan bata plastik membutuhkan cetakan berbahan besi, bervolume 1.235 $\mathrm{cm}^{3}$. Cetakan bata plastik dipilih berbahan besi agar plastik tidak menempel pada cetakan dan mudah untuk dilepas dari cetakan. Proses pencetakan bata plastik dimulai dari:

1) Menuangkan lelehan plastik ke dalam cetakan hingga memenuhi seluruh volume cetakan bata plastik.

2) Diamkan lelehan plastik di dalam cetakan selama \pm 1 jam hingga bata plastik mengeras.

3) Setelah bata plastik mengeras dan suhu normal, lepaskan bata dari cetakannya.

4) Proses pencetakan dilakukan sebanyak sembilan kali perlakuan. Tiga buah bata plastik berjenis PP, tiga buah bata plastik berjenis PET, dan tiga buah bata plastik berjenis HDPE.

\section{E. Tahap Pengujian Kuat Tekan}

Tahap pengujian kuat tekan bata plastik dilakukan sebanyak tiga kali pengulangan di setiap jenisnya. Berdasarkan SNI 03-1974-1990 tentang Metode Pengujian Kuat Tekan, pengujian bata plastik melalui beberapa tahapan sebagai berikut:

1) Letakan benda uji pada mesin tekan di bagian tengah.

2) Jalankan mesin tekan dengan penambahan yang konstan berkisar antara 2 sampai 4 $\mathrm{kg} / \mathrm{cm}^{2}$ per detik.

3) Lakukan pembebanan sampai benda uji menjadi hancur dan catatlah beban maksimum yang terjadi selama pemeriksaan benda uji.

Rumus Pengujian Kuat Tekan:

Kuat Tekan Beton $=\frac{P}{A}\left(\mathrm{~kg} / \mathrm{cm}^{2}\right)$

Keterangan:

$P \quad:$ Beban Maksimum $(\mathrm{kg})$

$A$ : Luas Penampang $\left(\mathrm{cm}^{2}\right)$ 


\section{F. Harga Jual Bata Plastik}

Harga jual bata plastik akan dibandingkan dengan harga jual bata yang ada di pasaran. Harga jual bata plastik ditentukan dengan metode Markup pricing. Metode markup pricing umumnya digunakan oleh para pedagang. Para pedagang dalam menentukan harga jualnya dengan cara menambahkan markup yang diinginkan pada per satuan harga. Berikut adalah rumus untuk menghitung harga jual bata plastik (Toar, 2017):

$$
\begin{aligned}
& \text { Harga Pokok Produk } \left.=\frac{\text { Total Biaya Produksi }}{\text { Total Produksi Se Bulan }}\right) \\
& \text { Harga Jual }=\text { Biaya Produksi } \times(1+\text { Persentase MarkUp })
\end{aligned}
$$

\section{G. Analisis Data}

Analisis uji kuat tekan bata plastik jenis PP, bata plastik jenis PET, dan bata plastik jenis HDPE menggunakan pengujian t-test dimana nilai uji kuat tekan bata plastik merupakan kelompok eksperimen dan nilai uji kuat tekan bata merah merupakan kelompok kontrol. Pada penelitian ini menentukan hipotesis yaitu:

Ho : Nilai kuat tekan bata plastik lebih besar dari nilai kuat tekan bata merah $\mathrm{Ha}$ : Nilai kuat tekan bata plastik lebih kecil dari nilai kuat tekan bata merah

\section{HASIL DAN PEMBAHASAN}

\section{A. Proses Pembuatan Bata Plastik}

Bata plastik adalah salah satu bata alternatif yang berpotensi bisa digunakan sebagai unsur bangunan dalam pembuatan konstruksi bangunan yang berbahan dasar terbuat dari sampah plastik tanpa bahan campuran lainnya. Berdasarkan penelitian yang dilakukan, alur proses pembuatan bata plastik dapat dilihat pada Gambar 1 .

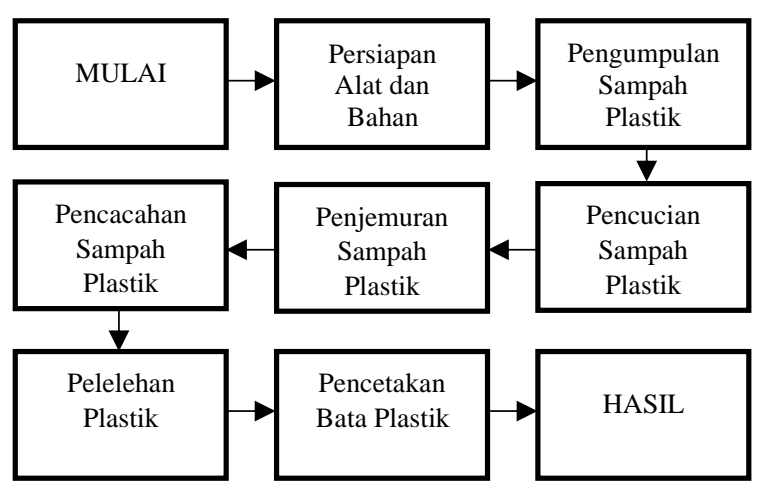

Gambar 1. Alur Proses Pembuatan Bata Plastik 
Tabel 1. Proses Pembuatan Bata Plastik

\begin{tabular}{|c|c|c|c|c|c|c|c|}
\hline Jenis Plastik* & $\begin{array}{c}\text { Massa } \\
\text { Jenis } \\
\left(\mathrm{g} / \mathrm{cm}^{3}\right)\end{array}$ & $\begin{array}{l}\text { Kode } \\
\text { Plastik }\end{array}$ & $\begin{array}{c}\text { Berat } \\
\text { Plastik } \\
(\mathrm{Kg})\end{array}$ & $\begin{array}{l}\text { Perco- } \\
\text { baan } \\
\text { ke- }\end{array}$ & $\begin{array}{c}\text { Suhu } \\
\text { Pelelehan } \\
\left({ }^{\circ} \mathrm{C}\right)\end{array}$ & $\begin{array}{c}\text { Lama } \\
\text { Pelelehan** } \\
\text { (Menit) }\end{array}$ & $\begin{array}{l}\text { Berat Bata } \\
\quad(\mathrm{kg})\end{array}$ \\
\hline \multirow{3}{*}{$\begin{array}{l}\text { Polypropylen } \\
(P P)\end{array}$} & \multirow{3}{*}{0,8776} & \multirow{3}{*}{ PP } & \multirow{3}{*}{1} & 1 & 165 & 84 & 0,9 \\
\hline & & & & 2 & 165 & 87 & 0,9 \\
\hline & & & & 3 & 165 & 85 & 0,9 \\
\hline \multirow{3}{*}{$\begin{array}{l}\text { Polyethylene } \\
\text { Terephthalate }\end{array}$} & \multirow{3}{*}{1,4} & \multirow{3}{*}{ PET } & \multirow{3}{*}{1,7} & 1 & 200 & 244 & 1,5 \\
\hline & & & & 2 & 200 & 246 & 1,5 \\
\hline & & & & 3 & 200 & 242 & 1,5 \\
\hline \multirow{3}{*}{$\begin{array}{l}\text { High Density } \\
\text { Polyethylene }\end{array}$} & \multirow{3}{*}{0,965} & \multirow{3}{*}{ HDPE } & \multirow{3}{*}{1,2} & 1 & 134 & 300 & 1,1 \\
\hline & & & & 2 & 134 & 310 & 1,1 \\
\hline & & & & 3 & 134 & 311 & 1,1 \\
\hline
\end{tabular}

Keterangan: *Biru = Warna Bata PP; Merah Muda = Warna Bata PET; Hitam = Warna Bata HDPE

**Warna menandakan waktu tercepat pelelehan bata plastik pada tiap jenis plastik

Proses pembuatan bata plastik yang terbuat dari sampah plastik seperti gelas plastik, botol mineral dan botol oli didapatkan di pengepul barang rongsokan, di bengkel-bengkel motor ataupun mengumpulkan di TPS sekitar daerah tempat tinggal, yaitu TPS di Kecamatan Sungai Raya. Sampah plastik jenis Polypropylene (PP), Polyethylene Terephthalate (PET), dan High Density Polyethylen (HDPE) digunakan sebagai bahan untuk pembuatan bata plastik. Berdasarkan penelitian yang telah dilakukan, proses pelelehan plastik membutuhkan waktu yang berbeda-beda untuk setiap jenisnya, dimana proses pelelehan plastik dapat dilihat pada Tabel 1. Penentuan titik leleh diperlukan untuk mengetahui waktu yang diperlukan masing-masing jenis plastik untuk meleleh. Setelah plastik meleleh, kemudian langsung dimasukkan ke dalam cetakan berbentuk persegi panjang bervolume $1.235 \mathrm{~cm}^{3}$ yang sebelumnya dilumasi dengan pelumas singer oil agar tidak lengket, lalu sedikit di-press supaya padat. Lamanya proses pelelehan plastik sehingga mencapai titik leleh dapat dilihat pada Tabel 1.

Berdasarkan Tabel 1, pembuatan bata plastik jenis PP dengan berat sampah plastik sebanyak $1 \mathrm{~kg}$ menghasilkan berat bata plastik bersih sebesar $0,9 \mathrm{~kg}$. Proses pelelehan sampah plastik jenis PP dengan suhu sebesar $165{ }^{\circ} \mathrm{C}$ (Karuniastuti, 2013) yang memerlukan waktu paling cepat terdapat pada pengulangan pertama yaitu selama 84 menit. Pembuatan bata plastik jenis PET dengan berat sampah plastik sebanyak $1,7 \mathrm{~kg}$ menghasilkan berat bata plastik bersih sebesar 1,5 kg. Proses pelelehan sampah plastik jenis PET dengan suhu sebesar $200^{\circ} \mathrm{C}$ (Okatama, 2016) memerlukan waktu yang paling lama pada pengulangan kedua yaitu selama 246 menit. Proses pelelehan sampah plastik jenis HDPE memerlukan waktu yang lebih lama dibandingkan dengan sampah plastik jenis PP dan PET. Hal ini dapat dilihat pada Tabel 1, yang menunjukkan bahwa waktu pelelehan pada pengulangan pertama, kedua, dan ketiga lebih lama dibandingkan dengan kedua jenis sampah plastik lainnya. Pembuatan bata plastik jenis HDPE dengan berat sampah plastik sebanyak $1,2 \mathrm{~kg}$ menghasilkan berat bata plastik bersih sebesar $1,1 \mathrm{~kg}$. Proses pelelehan sampah plastik jenis HDPE menggunakan suhu sebesar $134{ }^{\circ} \mathrm{C}$ (Rahmawati, 2017) memerlukan waktu yang lebih cepat untuk meleleh pada pengulangan pertama yaitu selama 300 menit. 


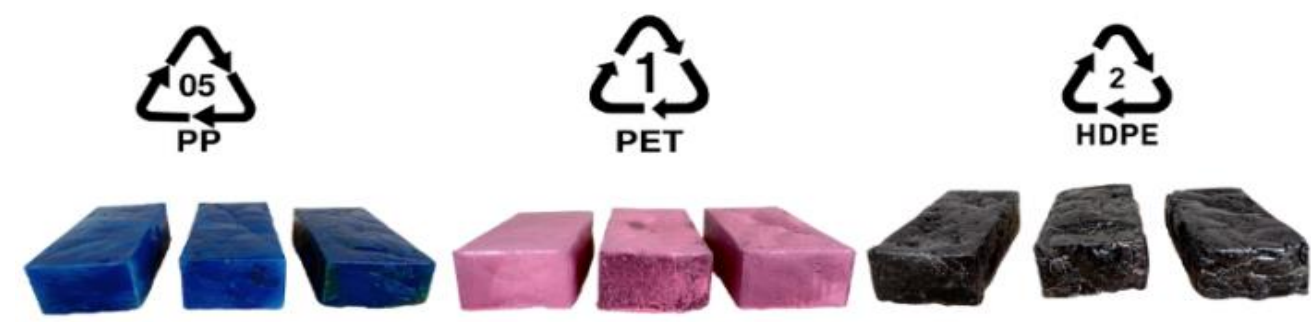

Gambar 2. Bata Plastik Berdasarkan Jenis

\section{B. Uji Kuat Tekan Bata Plastik}

Kuat tekan merupakan salah satu parameter yang digunakan untuk mengetahui kekuatan benda untuk mengetahui kekuatan atau kemampuan suatu material untuk menahan tekanan atau beban. Hal ini sesuai dengan pernyataan Pramono, (2014) yang menyatakan bahwa nilai kuat tekan bata diperlukan untuk mengetahui kekuatan maksimum dari suatu benda untuk menahan tekanan atau beban hingga retak dan pecah. Kualitas bata biasanya ditunjukkan oleh besar kecilnya kuat tekan. Namun besar kecilnya kuat tekan sangat dipengaruhi oleh suhu atau tingkat pembakaran, porositas dan bahan dasar. Penelitian ini menggunakan bata merah sebagai uji kontrol yang akan dijadikan pembanding antara bata plastik jenis PP, bata plastik jenis PET, dan bata plastik jenis HDPE. Berdasarkan penelitian yang dilakukan, diperoleh nilai kuat tekan bata plastik yang diuji pada Laboratorium Bahan dan Konstruksi Fakultas Teknik Universitas Tanjungpura, Pontianak pada Tabel 2.

Tabel 1. Nilai Uji Kuat Tekan Bata Plastik

\begin{tabular}{|c|c|c|c|c|c|c|c|}
\hline Percobaan & Kode* & $\begin{array}{c}\text { Tanggal } \\
\text { Pembuat } \\
\text { - an }\end{array}$ & $\begin{array}{c}\text { Tanggal } \\
\text { Uji }\end{array}$ & $\begin{array}{l}\text { Berat } \\
(\mathrm{kg})\end{array}$ & $\begin{array}{l}\text { Beban } \\
\mathrm{P}(\mathrm{kN})\end{array}$ & $\begin{array}{c}\text { Beban } \\
\text { Load } \\
(\mathrm{kg})\end{array}$ & $\begin{array}{c}\text { Kuat } \\
\text { Tekan** } \\
\left(\mathrm{kg} / \mathrm{cm}^{2}\right)\end{array}$ \\
\hline I & \multirow{3}{*}{ PP } & \multirow{3}{*}{$\begin{array}{c}01 / 02 / 20 \\
21\end{array}$} & \multirow{3}{*}{$\begin{array}{c}17 / 02 / 20 \\
21\end{array}$} & \multirow{3}{*}{0,9} & 455 & 46,397 & 244 \\
\hline II & & & & & 460 & 46,907 & 246 \\
\hline III & & & & & 465 & 47,416 & 249 \\
\hline $\mathrm{I}$ & \multirow{3}{*}{ PET } & \multirow{3}{*}{$\begin{array}{c}02 / 02 / 20 \\
21\end{array}$} & \multirow{3}{*}{$\begin{array}{c}17 / 02 / 20 \\
21\end{array}$} & \multirow{3}{*}{1,5} & 175 & 17,845 & 93 \\
\hline II & & & & & 180 & 18,354 & 96 \\
\hline III & & & & & 200 & 20,394 & 107 \\
\hline $\mathrm{I}$ & \multirow{3}{*}{ HDPE } & \multirow{3}{*}{$\begin{array}{c}03 / 02 / 20 \\
21\end{array}$} & \multirow{3}{*}{$\begin{array}{c}17 / 02 / 20 \\
21\end{array}$} & \multirow{3}{*}{1,1} & 300 & 30,591 & 160 \\
\hline II & & & & & 320 & 32,63 & 171 \\
\hline III & & & & & 310 & 31,611 & 166 \\
\hline $\mathrm{I}$ & \multirow{3}{*}{$\begin{array}{l}\text { BATA } \\
\text { MERAH }\end{array}$} & & & \multirow{3}{*}{1,4} & 200 & 20,387 & 226 \\
\hline II & & & & & 210 & 21,406 & 237 \\
\hline III & & & & & 210 & 21,406 & 237 \\
\hline
\end{tabular}

Keterangan: *Biru= Warna Bata PP; Merah Muda= Warna Bata PET; Hitam= Warna Bata HDPE; Merah Bata $=$ Warna Bata Merah

**Warna menandakan kuat tekan paling besar pada tiap jenis bahan

Menurut Said dan Sungkono (2016) menyebutkan bahwa bahan dinding dari sampah plastik merupakan bahan dinding alternatif hemat energi yang memiliki responsibilitas yang tinggi terhadap lingkungan termal sehingga dapat digunakan sebagai bahan dinding luar, dinding pagar maupun ruang dalam suatu bangunan. Material yang dihasilkan memiliki variasi warna yang menarik sehingga material ini dapat digunakan sebagai bahan penyekat antar ruangan di dalam bangunan maupun sebagai kulit bangunan tanpa 
melalui proses pengecatan lagi. Hal ini sesuai dengan penelitian Pramono, (2014) yang menyatakan bahwa hasil pengujian kuat tekan bata dengan variasi persentase sampah akan meningkatkan kuat tekan bata yang ada. Pemanfaatan sampah plastik sebagai bahan baku pembuatan bata merah dengan penambahan 10-30\% sampah plastik akan menghasilkan bata merah tingkat I dengan kuat tekan rata-rata diatas $100 \mathrm{~kg} / \mathrm{cm}^{2}$. Sebelum pemakaian atau pemasangan bata plastik tersebut dengan syarat memerlukan proses perendaman di dalam air (Pramono, 2014).

Penelitian ini membuktikan bahwa bata plastik memiliki tingkat kekuatan yang telah diuji kemampuannya jika dibandingkan dengan baku mutu, bata plastik memiliki nilai kuat tekan yang lebih tinggi daripada standar batu bata yang telah ditetapkan dalam SNI 152094-2000, pada SNI tentang bata merah pejal untuk pasangan dinding, batu bata tertinggi yaitu pada nilai kelas $150 \mathrm{~kg} / \mathrm{cm}^{2}$ dan bata plastik senilai $246 \mathrm{~kg} / \mathrm{cm}^{2}$. Parameter yang diuji pada penelitian ini adalah kuat tekan pada bata plastik. Hal ini dikarenakan pengujian kuat tekan diperlukan untuk melihat kualitas dari bata plastik. Pernyataan ini sejalan dengan penelitian Pramono (2014), yang mengatakan bahwa standar pengujian kuat tekan bata plastik diperlukan untuk menjamin kualitas bata pengganti yang baik.

\section{Analisis Uji Kuat Tekan}

Hasil analisis nilai uji kuat tekan bata plastik jenis PP, PET, dan HDPE akan dibandingkan dengan bata merah, dimana jumlah bata merah sebagai kontrol yang digunakan sebanyak 3 buah. Hasil analisis nilai uji kuat tekan bata plastik akan dibandingkan dengan nilai uji kuat tekan rata-rata dari ketiga bata merah yang digunakan, dimana jumlah bata merah yang digunakan menyesuaikan jumlah pengulangan dalam pengujian pada penelitian. Hasil analisis nilai uji kuat tekan bata plastik jenis PP, bata plastik jenis PET, bata plastik jenis HDPE, dan bata merah dapat dilihat pada Tabel setiap jenis bata plastik berikut:

1) Bata Plastik Jenis Polypropylene (PP)

Tabel 3. T-test Nilai Uji Kuat Tekan Bata Plastik Jenis PP dan Bata Merah

\begin{tabular}{l|rl}
\hline \multicolumn{1}{c|}{ Keterangan } & \multicolumn{1}{c}{ PP } & BATA MERAH \\
\hline Mean & 246,333333 & 233,3333333 \\
Variance & 6,33333333 & 40,33333333 \\
& & DERAJAT \\
$D f$ & 4 & KEBEBASAN \\
$t$ Stat & 3,29610159 & NILAI T HITUNG \\
$t$ Critical two-tail & 2,77644511 & NILAI T TABEL \\
\hline
\end{tabular}

Berdasarkan hasil analisis nilai T Hitung $\geq$ dari T Tabel, maka nilai Ho diterima. Artinya nilai kuat tekan bata plastik jenis PP lebih besar daripada nilai kuat tekan bata merah.

2) Bata Plastik Jenis Polyethylene Terephthalate (PET)

Tabel 4. T-test Nilai Uji Kuat Tekan Bata Plastik Jenis PET dan Bata Merah

\begin{tabular}{lrll}
\hline \multicolumn{1}{c|}{ Keterangan } & \multicolumn{1}{c|}{ PET } & BATA MERAH \\
\hline Mean & 98,6666667 & 233,3333333 \\
Variance & 54,3333333 & 40,33333333 \\
& & DERAJAT \\
$D f$ & 4 & KEBEBASAN \\
$t$ Stat & $-23,972989$ & NILAI T HITUNG \\
$t$ Critical two-tail & 2,77644511 & NILAI T TABEL \\
\hline
\end{tabular}


Berdasarkan hasil analisis nilai T Hitung < dari T Tabel, maka nilai Ho ditolak. Artinya nilai kuat tekan bata plastik jenis PET lebih kecil daripada nilai kuat tekan bata merah.

3) Bata Plastik Jenis High Density Polyethylene (HDPE)

Tabel 5. T-test Nilai Uji Kuat Tekan Bata Plastik Jenis HDPE dan Bata Merah

\begin{tabular}{lcl}
\hline \multicolumn{1}{c}{ Keterangan } & HDPE & BATA MERAH \\
\hline Mean & 165,666667 & 233,3333333 \\
Variance & 30,3333333 & 40,33333333 \\
& & DERAJAT \\
Df & 4 & KEBEBASAN \\
$t$ Stat & $-13,942097$ & NILAI T HITUNG \\
$t$ Critical two-tail & 2,77644511 & NILAI T TABEL \\
\hline
\end{tabular}

Berdasarkan hasil analisis nilai T Hitung < dari T Tabel, maka nilai Ho ditolak. Artinya nilai kuat tekan bata plastik jenis HDPE lebih kecil daripada nilai kuat tekan bata merah. Hasil analisis ini menunjukkan bahwa nilai uji kuat tekan bata plastik jenis PP lebih besar daripada nilai uji kuat tekan bata merah.

\section{Nilai Jual Bata Plastik}

Berdasarkan UU No. 18/2008 tentang Pengelolaan Sampah, salah satu aktivitas yang dapat dilakukan adalah recycle (daur ulang), yaitu memanfaatkan kembali sampah setelah mengalami pengolahan. Bata plastik adalah salah satu usaha kreatif yang dapat dilakukan untuk aktivitas recycle ini. Pembuatan bata plastik tidak sulit, namun memerlukan ketelatenan dan usaha semaksimal mungkin. Hal ini dibuktikan dengan nilai uji kuat tekan yang didapatkan dari penelitian yang menunjukkan bahwa standar bata plastik telah memenuhi standar SNI 15-2094-2000.

Bata plastik yang telah dibuat memiliki potensi nilai ekonomi yang dapat dijual karena mampu bersaing dengan bata pada umumnya. Penentuan harga jual merupakan salah satu keputusan penting karena harga yang ditetapkan harus dapat menutup semua biaya dan dalam rangka mendapatkan laba yang diharapkan, dimana faktor biaya merupakan faktor utama dalam menentukan harga jual (Toar, 2017).

Tabel 6. Taksiran Jumlah Produk yang Dihasilkan

\begin{tabular}{|c|c|c|c|c|}
\hline \multirow{2}{*}{ Jenis Bata } & \multirow{2}{*}{ Gambar Bata } & \multicolumn{3}{|c|}{ Taksiran Jumlah Produk Yang Dihasilkan } \\
\cline { 3 - 5 } & & Per Hari & Per Minggu & Per Bulan \\
\hline PP & & 3 & 21 & 90 \\
\hline PET & & 3 & 21 & 90 \\
\hline HDPE & & 3 & 21 & 90 \\
\hline
\end{tabular}

\section{E. Perhitungan Harga}

1). Skenario perhitungan I dimaksudkan untuk menghitung harga jual bata plastik tanpa memasukkan harga plastik sebagai bahan baku pembuatan bata plastik, hal ini dilakukan untuk mengetahui harga jual bata plastik jika sampah plastik didapatkan secara langsung (tanpa pembelian). 
2). Skenario perhitungan II dimaksudkan untuk menghitung harga jual bata plastik dengan memasukkan harga plastik sebagai bahan baku pembuatan bata plastik, hal ini dilakukan untuk mengetahui harga jual bata plastik jika sampah plastik didapatkan dengan pembelian dan untuk pembuatan bata plastik dalam produksi skala besar.

\section{F. Perbandingan Perhitungan Skenario I dan Skenario II}

Berdasarkan hasil perhitungan harga jual bata plastik yang melakukan dua skenario perhitungan yaitu Skenario I dan Skenario II perbandingan harga jual bata plastik dapat dilihat pada Tabel 7.

Tabel 7. Perbandingan Harga Jual Plastik

\begin{tabular}{|c|c|c|}
\hline \multirow{2}{*}{ Jenis Bata Plastik } & SKENARIO I & SKENARIO II \\
\cline { 2 - 3 } & Harga Jual & Harga Jual \\
\hline PP & Rp1.907,00 & Rp2.867,00 \\
\hline PET & Rp3.024,00 & Rp4.624,00 \\
\hline HDPE & Rp3.463,00 & Rp3.944,00 \\
\hline
\end{tabular}

Hasil perhitungan Skenario I tanpa memasukkan harga beli plastik sebagai bahan baku pembuatan bata plastik menunjukkan bahwa bata plastik jenis PP memiliki harga jual yang paling murah dibandingkan dengan bata plastik jenis lainnya, yaitu seharga Rp1.907,00/bata, sedangkan hasil perhitungan Skenario II dengan memasukkan harga beli plastik sebagai bahan baku pembuatan bata plastik menunjukkan bahwa bata plastik jenis PP memiliki harga jual yang paling murah dibandingkan dengan bata plastik jenis lainnya, yaitu seharga Rp2.867,00/bata. Meskipun harga jual bata plastik jenis PP pada Skenario I dan Skenario II paling murah dibandingkan bata plastik lainnya, namun bata plastik jenis ini memiliki kualitas yang paling baik dibandingkan bata plastik jenis PET dan HDPE. Pada perhitungan harga jual bata plastik skenario I harga jual yang termahal terdapat pada bata plastik jenis HDPE dengan harga jual sebesar Rp3.464,00/bata, sedangkan harga jual bata plastik yang termahal pada skenario II yaitu bata plastik jenis PET sebesar Rp4.624,00/bata.

Berdasarkan harga jual bata di Kota Pontianak (Toko Bangunan Mitra Jaya) yang diperoleh dengan melakukan tinjauan langsung ke toko bangunan, harga jual bata merah di pasaran toko seharga Rp3.000,00/bata. Jika dibandingkan dengan harga jual bata plastik jenis PET dan HDPE, dapat dikatakan bahwa harga jual bata plastik lebih mahal dibandingkan dengan bata merah pada umumnya. Sedangkan harga jual bata plastik jenis PP lebih murah dari bata merah, namun memiliki kualitas bata yang baik.

\section{PENUTUP}

\section{Kesimpulan}

Kesimpulan yang diperoleh dari penelitian ini yaitu:

1. Proses pembuatan bata plastik jenis PP, PET dan HDPE yaitu pengumpulan sampah plastik berdasarkan jenisnya, pencucian sampah plastik, penjemuran sampah plastik, pencacahan sampah plastik, pelelehan sampah plastik, dan pencetakan bata plastik. Bata plastik jenis PET memerlukan sampah yang paling banyak, yaitu 5,1 kg untuk pembuatan tiga bata plastik, bata jenis HDPE memerlukan sampah plastik sebanyak 3,6 kg untuk pembuatan tiga bata plastik, dan bata plastik jenis PP memerlukan sampah $3 \mathrm{~kg}$ sampah plastik untuk pembuatan tiga bata plastik.

2. Berdasarkan uji kuat tekan bata plastik jenis PP memiliki kualitas kuat tekan yang paling tinggi, dengan nilai uji kuat tekan rata-rata sebesar $246 \mathrm{~kg} / \mathrm{cm}^{2}$, nilai rata-rata 
uji kuat tekan bata plastik jenis HDPE sebesar $166 \mathrm{~kg} / \mathrm{cm}^{2}$, dan nilai rata-rata uji kuat tekan bata plastik jenis PET sebesar $98,7 \mathrm{~kg} / \mathrm{cm}^{2}$.

3. Harga jual bata plastik tanpa memasukkan harga beli plastik dalam proses produksi, jenis PP seharga Rp1.907,00/bata, harga jual bata plastik jenis PET seharga Rp3.024,00/bata, dan harga jual bata plastik jenis HDPE seharga Rp3.464,00/bata. Sedangkan harga jual bata plastik dengan memasukkan harga beli plastik dalam proses produksi, jenis PP seharga Rp2.867,00/bata, harga jual bata plastik jenis PET seharga Rp4.624,00/bata, dan harga jual bata plastik jenis HDPE seharga Rp3.944,00/bata.

\section{Saran}

Berdasarkan penelitian yang telah dilakukan saran yang dapat diberikan yaitu dilakukan penelitian lebih lanjut dengan menggunakan variasi bahan jenis plastik lainnya, diperlukan penelitian lanjutan dengan melakukan pengujian lebih lengkap, tidak hanya menguji kuat tekan saja, misalnya uji bakar terhadap ketahanan produk bata plastik, selain itu diperlukan desain alat pelelehan bata plastik, dan rancangan bangunan pengaplikasian bata plastik.

\section{UCAPAN TERIMA KASIH}

Penulis mengucapkan terima kasih kepada dosen pembimbing Ibu Dian Rahayu Jati, S.T, M.Si dan Ibu Yulisa Fitrianingsih, S.T, M.T atas bimbingan, masukan, serta saran dalam menyelesaikan Tugas Akhir ini serta kepada keluarga dan semua pihak yang terlibat telah banyak membantu penulis selama proses pengerjaan penelitian.

\section{DAFTAR PUSTAKA}

BPS. 2020. Statistik Daerah Provinsi Kalimantan Barat 2020. Penerbit: Badan Pusat Statistik Provinsi Kalimantan Barat. ISSN: 2620-8830.

BPS. 2020. Statistik Lingkungan Hidup 2020. Penerbit: Badan Pusat Statistik. ISSN: 0216-6224.

Kamaliah, 2019. Pemanfaatan Limbah Sampah Plastik Menjadi Bata Beton. Media Ilmiah Teknik Lingkungan. Volume 4, Nomor 2.

Karuniastuti, N. 2013. Bahaya Plastik Terhadap Kesehatan dan Lingkungan. FORUM TEKNOLOGI. Vol. 03 No.1.

Okatama, I. 2016. Analisa Peleburan Limbah Plastik Jenis Polyethylene Terephthalate (PET) Menjadi Biji Plastik Melalui Pengujian Alat Pelebur Plastik. Jurnal Teknik Mesin. ISSN: 2089-7235.

Pramono, .S.A.; Watiningsih, T., dan Rustendi, I. 2014. Sampah Sebagai Bahan Baku Pembuatan Batu Bata. PROSIDING ISBN: 978-602-8047-99-9.

Rahmawati, A. 2017. Perbandingan Penggunaan Polypropylene (PP) dan High Density Polyethylene (HDPE) Pada Campuran Laston_Wc. Media Teknik Sipil. ISSN: 16933095.

Said, J., dan Sungkono. 2016. Pengolahan Sampah Plastik dan Tanaman Enceng Gondok Menjadi Bahan Bangunan Alternatif Hemat Energi. Prosiding Temu Ilmiah IPLB.

Sari, K.I., dan Nusa, A.B., 2019. Pemanfaatan Limbah Plastik HDPE (High Density Polyethylene) Sebagai Bahan Pembuatan Paving Block. Buletin Utama Teknik. ISSN: 2598-3814.

SNI 03-1974-1990. Tentang Metode Pengujian Kuat Tekan. Penerbit: Badan Standardisasi Nasional. ICS 91.100.20. 
SNI 15-2094-2000. Bata Merah Pejal Untuk Pasangan Dinding. Penerbit: Badan Standardisasi Nasional. ICS 91.100.20.

Toar, O.; Karamoy, H., dan Wokas, H. 2017. Analisis Perbandingan Harga Jual Produk Dengan Menggunakan Metode Cost Plus Pricing dan Mark Up Pricing Pada Dolphin Donuts Bakery. Jurnal EMBA. ISSN 2303-1174.

Undang-Undang Republik Indonesia Nomor: 18 Tahun 2008. Tentang Pengolahan Sampah. 